\title{
Iodine Concentrations Prior to Initial Incubation Do Not Impact the Bacterial Communities of Landlocked Fall Chinook salmon Eggs at the Eyed Stage of Development
}

\author{
David Bergmann ${ }^{1}$, Jesse Larson ${ }^{1}$, Taylor Liu ${ }^{1}$, Nathan Huysman ${ }^{2}$ and Michael E Barnes ${ }^{2 *}$ \\ ${ }^{1}$ Department of Science, Black Hills State University, Spearfish, South Dakota, 57799, USA
}

${ }^{2}$ South Dakota Department of Game, Fish and Parks, McNenny State Fish Hatchery, Spearfish, South Dakota, 57783, USA

Received: August 10, 2018; Accepted: August 23, 2018; Published: August 29, 2018

*Corresponding author: Michael E Barnes, South Dakota Department of Game, Fish and Parks, McNenny State Fish Hatchery, 19619 Trout Loop, Spearfish, South Dakota, 57783, USA, Tel: +605-642-6920; Fax:+605-642-6921; E-mail: mike.barnes@state.sd.us

\begin{abstract}
Using iodine solutions to disinfect newly-spawned salmonid eggs is well established. This study examined the bacterial communities of eggs from five landlocked Chinook salmon Oncorhynchus tshawytscha females subjected to 10-minute treatments' of 100,200 , or $400 \mathrm{mg} / \mathrm{l}$ of active iodine prior to hatchery incubation. Bacterial sampling of the eggs occurred prior to disinfection, immediately after disinfection and 28-days later at the eyed stage of development. Hatchery incubation water was also sampled. The number of cultivable bacteria on the external membrane of freshly-spawned eggs ranged from 10 to over 66 colony-forming units. All of the iodine treatments significantly reduced the number of bacteria compared to pretreatment samples, but there were no significant differences among the treatments. Numbers of cultivable bacteria on eggs at the eyed stage after 28 days of incubation were approximately $10^{5}$ times greater than those observed on the freshly-spawned eggs. There were no significant differences in egg survival among the iodine treatment groups. Acinetobacter dominated the egg surface prior to iodine disinfection, and Psychrobacter also was common. Flavobacterium was the most prevalent bacterial genus from eyed-eggs, representing over $43 \%$ of the sequences. Vibrio and Variovorax were also abundant. The bacterial flora of the hatchery water was dominated by Proteobacteria, especially Pseudomonas species, with Massilia, Zoogloea, Leptospirillum, and Rhodococcus also abundant. No effects of iodine treatment level on the abundance or genera of bacteria on eyed-eggs were evident.
\end{abstract}

Key Words: Iodine; disinfection; bacteria; Chinook salmon; Oncorhynchus tshawytscha;

\section{Introduction}

Disinfection using povidone iodine is routinely conducted when fish eggs are transferred between hatcheries or prior to egg introduction into a hatchery setting from non-hatchery environments $[1,19,22]$. However, the standard bath treatment of $100 \mathrm{mg} / \mathrm{L}$ active iodine for 10 minutes does not kill all of the bacteria attached the external egg membrane $[8,16,29]$.
Modifications to the standard treatment, such as using increased iodine concentrations, increased treatment duration, or increased treatment frequency, have all been evaluated with mixed results [11,17,29,30,31,35]. Measurements of treatment success typically involve bacterial evaluations immediately prior and after iodophor treatment, but no studies have examined the possible long-term effects of povidone iodine treatments on egg membrane bacterial communities.

Bacterial populations associated with the incubation of fall Chinook salmon Oncorhynchus tshawytscha eggs have been extensively studied, making it an ideal model to use for the determination of long-lasting iodine disinfection effects. Bacterial numbers and species in the ovarian fluid of spawning salmon, and the number and genera of bacteria on salmon eggs just prior to their placement in hatchery incubators and then 27 days later have been described $[9,10]$. Bacterial numbers were reported from regular sampling throughout the incubation of landlocked fall Chinook salmon eggs and from initial loading into trays until just prior to fry swim-up [5]. The bacterial communities present on the external egg membranes of hatchery incubated salmon eggs from the eyed-egg stage through fry hatch have also been examined [7]. Flavobacterium spp. on eggs and fry of Chinook salmon have also been recently studied [18].

The primary objective of this study was to examine the effects of three different initial povidone iodine disinfection treatments on bacterial numbers and genera present on the external egg membrane of landlocked fall Chinook salmon eggs four-weeks later at the eyed-stage of development.

\section{Materials and Methods}

\section{Spawning and Egg Incubation}

Spawning occurred at Whitlocks Spawning Station near Gettysburg, South Dakota, USA, on October 16, 2016. Eggs were 
collected by pneumatic extrusion from five female landlocked fall Chinook salmon, fertilized with pooled sperm, and waterhardened for one hour prior to four hour transport to the McNenny State Fish Hatchery, rural Spearfish, South Dakota. Immediately upon arrival at the hatchery, and prior to any iodine disinfection, 10 eggs from each spawn were removed, placed into plastic bags (Whirlpacs, Nasco, Fort Atkinson, Wisconsin, USA) containing $10 \mathrm{ml}$ distilled water and $500 \mathrm{mg} / \mathrm{L} \mathrm{MS}-222$ (Tricaine-S, tricaine methanesulfonate, Syndel USA, Ferndale, Washington, USA) for euthanasia and transported for 15-minutes to Black Hills State University in Spearfish, South Dakota for subsequent bacterial sampling.

The remaining eggs from each spawn were then split into three groups subjected to subsequent 10-minute povidone iodine (Western Chemical, Ferndale, Washington) treatments of 100,200 , or $400 \mathrm{mg} / \mathrm{L}$ of active iodine. After disinfection, 10 eggs were removed from each treatment of each spawn for bacterial sampling as described for the pre-treatment egg samples. The eggs from each treatment from each spawn were then inventoried using the water displacement method and placed into discrete vertical-flow incubation trays (Marisource, Puyallup, Washington, USA) [22]. Well water (11oC; total hardness $360 \mathrm{mg} / \mathrm{l} \mathrm{CaC03;}$ alkalinity as CaCO3, $210 \mathrm{mg} / \mathrm{L} ; \mathrm{pH}$ 7.6; total dissolved solids 390 $\mathrm{mg} / \mathrm{l}$ ) at $12 \mathrm{~L} /$ minute was used throughout incubation. Daily formalin treatments using Paracide-F (37\% formaldehyde, 6 to 14\% methanol, Western Chemical, Ferndale, Washington, USA) at a concentration of $1,667 \mathrm{mg} / \mathrm{l}$ for $15 \mathrm{~min}$ were administered with a Masterflex model 7524-00 microprocessor peristaltic pump (Cole-Parmer Instrument Company, Chicago, Illinois) once a day for four weeks. Dead eggs were removed on incubation day 28 (eyed egg stage) and the remaining viable eyed eggs were reinventoried by water displacement. Survival (\%) to eyed stage of development was determined by using the following formula: Survival $(\%)=100 \times[1-($ mortality at eyed stage $/$ initial egg number)]. Samples of 10 eggs from each of the treatment groups from each spawn were also collected on day 28 as described previously for the pre-incubation egg samples.

\section{Bacterial Sampling and Analysis}

After the eggs were received at Black Hills State University, they were rinsed three times in sterile Phosphate Buffered Saline (PBS) solution in a sterilized sieve, and then added to $3.0 \mathrm{ml}$ sterile PBS and vortexes vigorously for five minutes in sterile 15 $\mathrm{ml}$ falcon tubes. The remaining vortexes fluid was transferred to two sterile $1.5 \mathrm{ml}$ Eppendorf micro-centrifuge tubes and micro-centrifuged at 10,000 rpm for $10 \mathrm{~min}$. The supernate was removed with a sterile $1.0 \mathrm{ml}$ pipette tip. The pellet of material vortexes from eggs from one of each paired tubes was frozen at $-80^{\circ} \mathrm{C}$ for later DNA extraction. The pellet from the other tube of each pair was re-suspended in $330 \mu \mathrm{L}$ sterile PBS and vortexes. Three $100 \mu$ l portions of the re-suspended material were spread onto plates of R2A media with $50 \mu \mathrm{g} / \mathrm{ml}$ cycloheximide (three plates per sample) [23]. R2A agar plates were incubated four days at $20^{\circ}$ C. Bacterial Colony Forming Units (CFU) was estimated, and colony morphology recorded. All egg samples were handled similarly, except for the eyed-eggs collected on incubation day 28 where for the fluid from the vortexes eggs was diluted at $10^{-3}$ and $10^{-4}$ prior to being spread on the R2A agar plates.

Approximately four colonies nearest the center of an R2A agar plate of bacteria from each treatment were isolated on R2A agar. Isolates were gram-stained and tested for cytochrome oxidase, growth on citrate agar, reduction of nitrate to nitrite, and starch hydrolysis to divide them into phenotypic groups $[12,20,36]$. Seven representatives (one or two from each of four major phenotypic groups) were selected for genetic characterization. Genomic DNA was extracted using a DN Easy Blood and Tissue kit (Qiagen, Inc.) using the gram-negative bacteria protocol. An approximately 1460 BP region of the 16S rRNA gene was amplified by PCR with primers 27F ( $5^{\prime}$ AGTTTGATCMTGGCTCAG $3^{\prime}$ ) and 1492R (5'-GGT TAC CTT GTT ACG ACT T-3') [32]. The reaction mixture $(15 \mu \mathrm{l})$ contained 5 Prime HotMasterMix (2.5x), 1.5 ? of $10 \mathrm{mg} / \mathrm{ml}$ bovine serum albumin, primers $(10 \mu \mathrm{m})$ and $2 \mu$ l genomic DNA. The PCR reaction used pre-denaturation at $94^{\circ} \mathrm{C}$ for $2 \mathrm{~min} ; 32$ cycles of denaturation at $94^{\circ} \mathrm{C}$ for 30 sec, annealing at $57^{\circ} \mathrm{C}$ for $15 \mathrm{sec}$ and extension at $65^{\circ} \mathrm{C}$ for 4 min; and a final extension at $65^{\circ} \mathrm{C}$ for $7 \mathrm{~min}$. After cleaning the amplified product with ExoSAP-IT (Affymetrix, Santa Clara, California USA) sequencing was performed with primers $27 \mathrm{~F}$ (AGAGTTTGATCMTGGCTCAG), 338F (ACTCCTACGGGAGGCAGCAG) and 1390R (CGGTGTGTACAAGGCCC) ${ }^{32-34}$ using Big Dye Terminator v1.1 Cycle Sequencing Kit in ABI 3130xl Genetic Analyzer (Applied Biosystems, Foster City, California USA). 16S rDNA sequences were categorized to taxa using the Classifier program [33] at the Ribosomal database website (https://rdp.cme.msu.edu/).

The water used to incubate the eggs was sampled for bacteria by filtering approximately $20 \mathrm{~L}$ of water through a $0.22 \mu \mathrm{m}$ pore size Sterivex GP filter unit (Millipore Sigma, Merck KGaA, Darmstadt, Germany) using a Masterflex E/S portable sampling peristaltic pump (Cole-Parmer Instrument Company, Chicago, Illinois, USA) to collect bacterial cells. DNA was extracted from the membrane using a Power Water DNA extraction kit (MoBio, Inc, Carlsbad, California, USA).

\section{S rDNA Library Preparation}

Genomic DNA was extracted from material vortexes from eggs using the DNeasy Blood and Tissue kit (Qiagen, Inc., Hilden, Germany) using the protocol outlined for gram-positive bacteria. A negative control, which followed the same extraction protocol but without vortexes material, was also performed. DNA concentrations were determined initially using a NanoDrop spectrophotometer (Fisher Scientific International, Inc., Hampton, New Hampshire, USA) Samples with concentrations less than $5 \mathrm{ng} / \mu \mathrm{L}$ were cleaned and concentrated with Zymogen Research DNA Clean \& Concentrator-5 kit (Zymo Research, Irvine, California, USA). Samples $>5.0 \mathrm{ng} / \mu \mathrm{L}$ were diluted to $5.0 \mathrm{ng} / \mu \mathrm{L}$ and 3.0 $\mu \mathrm{L}$ used in MiSeq library preparation; samples $<5.0 \mathrm{ng} /$ $\mu \mathrm{L}$ used $6 \mu \mathrm{L}$ of DNA. 
Bacterial 16S rDNA metagenomic libraries for Next Gen sequencing were prepared. The Qubit Fluorometer 2.0 (Invitrogen, Carlsbad, California, USA was used to determine DNA concentration. Libraries were prepared with an Next era kit (Illumina, San Diego, California, USA). DNA was diluted according to manufacturer's instructions to normalize DNA concentrations among samples. While all samples from eggs resulted in $16 \mathrm{~S}$ rDNA libraries, no library resulted from the negative control. Library preparation was done according to Illumina (San Diego, California, USA) "16S Metagenomic Sequencing Library Preparation,” 15044223 Rev. B. (Qiagen, Inc., Hilden, Germany). The 16S rDNA library was sequenced run on the MiSeq, and results were sent to Base Space (Illumina, San Diego, California, USA). MiSeq automatically removes primer sequences during the quality control steps in Base Space.

\section{S rDNA Sequence Analysis}

16S rDNA sequences from samples were downloaded from Illumina's Base Space in .fastq format and uploaded to the CLC Bio Workbench via Illumina import. Samples were imported as "Paired Reads, Paired-end" (forward-reverse) 200 and 600 minimum and maximum distances, respectively. "Remove Failed Reads" was also selected, and quality scores were set to the NCBI/Sanger or Illumina Pipeline 1.8 and later. Paired sequences were merged with mismatch costs at 1 , minimum score of 40 , gap cost of 4, and maximum unaligned end mismatches of 5 . "Fixed Length Trimming" set all sequences to a uniform length. Samples were filtered based on the number of reads with 100 as the minimum number of reads and 50 as the minimum percent from the median. "Copy Samples with Sufficient Coverage" was chosen. OTU (Operational Taxonomic Unit) clustering using 97\%
SILVA database with the following parameters: $97 \%$ similarity percentage; 2 minimum occurrences; 3 chimera crossover cost; 6 Kmer size; and with "Find Best Match" chosen. OTUs with low abundances were removed at 10 minimum combined abundance. The resulting alignment was combined with an alignment of assignment Thermococcus from accession Y16227 downloaded from NCBI.

\section{Statistical Analysis}

All data analysis was done using SPSS (9.0) statistical analysis program (SPSS, Chicago, Illinois), with significance predetermined at $\mathrm{p}<0.05$. Bacterial Colony Forming Unit (CFU) data was analyzed using the Kruskal-Wallis one-way Analysis of Variance with Tukey's HSD test used if there was a significant difference among the treatments [15].

\section{Results}

The number of cultivable bacteria on the external membrane of freshly-spawned Chinook salmon eggs ranged from 10 to over $66 \mathrm{CFU}$ table 1 . All of the iodine treatments significantly reduced the number of CFU in comparison to the pre-treatment samples ( $p=0.013$ ), but there were no significant differences in CFU among the three iodine treatments. Numbers of cultivable bacteria on eggs at the eyed stage after 28 days of incubation were approximately 105 times greater than those observed on the freshly-spawned eggs. The density of bacteria on eggs from the spawns of different females varied greatly, although density of bacteria on eggs from different iodine treatments collected from the same female were similar. There was no significant difference in egg survival among the iodine treatment groups.

Table 1: Colony Forming Units (CFU) per egg from eyed landlocked fall Chinook salmon eggs subjected to one of three pre-incubation iodine treatments. Eyed egg survival is the mean of all three iodine treatment groups. Mean values followed by different letters are significantly different $(\mathrm{p}<0.05)$

\begin{tabular}{|c|c|c|c|c|c|}
\hline & & \multicolumn{3}{|c|}{ Iodine Concentration (mg/L) } & \\
\hline Female & Pre-treatment & $\mathbf{1 0 0}$ & $\mathbf{2 0 0}$ & $\mathbf{4 0 0}$ & Survival (\%) \\
\hline 1 & 12.61 & $4.22 \times 105$ & $1.63 \times 105$ & $2.68 \times 105$ & $11.95(0.73)$ \\
\hline 2 & 10 & $9.60 \times 105$ & $15.40 \times 105$ & $15.30 \times 105$ & $18.53(1.10)$ \\
\hline 3 & 15.21 & $1.32 \times 105$ & $1.46 \times 105$ & $2.19 \times 105$ & $29.46(1.19)$ \\
\hline 4 & 65.63 & $10.50 \times 105$ & $13.30 \times 105$ & $8.20 \times 105$ & $39.77(5.11)$ \\
\hline 5 & 50.85 & $30.20 \times 105$ & $17.30 \times 105$ & $23.80 \times 105$ & $16.30(0.75)$ \\
\hline Mean (SE) & $30.86(11.45) \mathrm{z}$ & $11.17 \times 105(5.65 \times 105) \mathrm{y}$ & $9.82 \times 105(3.84 \times 105) \mathrm{y}$ & $10.43 \times 105(4.58 \times 105) \mathrm{y}$ & $14.73(2.88)$ \\
\hline
\end{tabular}

Acinetobacter (16S rDNA sequence identical to A. iwoffii) was the primary bacteria identified from the 16S rDNA sequences (96.9\% of sequences) obtained from salmon eggs prior to iodine disinfection. This Acinetobacter OTU was not observed in hatchery water. Pseudomonas sp. $(0.4 \%)$ and Chryseobacterium $\mathrm{sp},(0.5 \%)$ were less common, while all other OTUs represented less than $0.2 \%$ sequences each.

Flavobacterium spp. OTUs, which represented over $43 \%$ of the sequences, dominated the $16 \mathrm{~S}$ rDNA sequences from eyed-eggs table 2. Vibrio (sequence identical to V. metschnikovii) (23.50\%) and Variovorax species (16.64\%) were also abundant. No effects of iodine treatment level on the abundance or genera of bacteria on eyed-eggs were evident.

The bacterial flora of the hatchery water was dominated by Proteobacteria, especially Pseudomonas species table 3. Massilia, Zoogloea, Leptospirillum, and Rhodococcus were also abundant. Flavobacterium constituted less than $0.5 \%$ of the $16 \mathrm{~S}$ rDNA sequences from hatchery water. Over 15 other bacterial genera were sampled in the hatchery water. 
Table 2: Mean $( \pm$ SE) percentages of bacteria genera from landlocked fall Chinook salmon eyed eggs. Genera comprising less than $0.59 \%$ of those sampled are not listed. The phylum (or class for Proteobacteria) of each genus is also included.

\begin{tabular}{|c|c|c|c|c|c|}
\hline \multirow[b]{2}{*}{ Genus } & \multirow[b]{2}{*}{ Phylum/Class } & \multicolumn{3}{|c|}{ Iodine Concentration (mg/L) } & \multirow[b]{2}{*}{ Overall Mean } \\
\hline & & 100 & 200 & 400 & \\
\hline Flavobacterium & Bacteroidetes & $42.65 \pm 2.80$ & $43.54 \pm 3.88$ & $44.68 \pm 1.94$ & $43.62 \pm 1.61$ \\
\hline Vibrio & g-Proteobacteria & $24.69 \pm 3.82$ & $25.93 \pm 7.62$ & $19.54 \pm 4.28$ & $23.38 \pm 3.03$ \\
\hline Variovorax & b-Proteobacteria & $17.20 \pm 1.81$ & $15.73 \pm 2.35$ & $17.30 \pm 1.92$ & $16.75 \pm 1.11$ \\
\hline Pedobacter & Bacteroidetes & $5.27 \pm 1.08$ & $4.59 \pm 1.13$ & $6.42 \pm 1.82$ & $5.43 \pm 0.77$ \\
\hline Acidovorax & b-Proteobacteria & $2.73 \pm 0.59$ & $2.80 \pm 0.98$ & $2.34 \pm 0.33$ & $2.62 \pm 0.37$ \\
\hline OM43 clade & b-Proteobacteria & $1.50 \pm 0.27$ & $1.37 \pm 0.26$ & $1.97 \pm 0.50$ & $1.61 \pm 0.20$ \\
\hline Methylotenera & b-Proteobacteria & $1.22 \pm 0.27$ & $0.93 \pm 0.22$ & $1.95 \pm 0.96$ & $1.37 \pm 0.33$ \\
\hline Achromobacter & b-Proteobacteria & $0.92 \pm 0.57$ & $1.13 \pm 0.36$ & $0.65 \pm 0.14$ & $0.90 \pm 0.22$ \\
\hline Pseudomonas & g-Proteobacteria & $0.73 \pm 0.28$ & $0.70 \pm 0.10$ & $1.23 \pm 0.53$ & $0.89 \pm 0.20$ \\
\hline Massilia & b-Proteobacteria & $0.60 \pm 0.17$ & $0.65 \pm 0.15$ & $0.73 \pm 0.08$ & $0.66 \pm 0.08$ \\
\hline Acinetobacter & g-Proteobacteria & $0.59 \pm 0.11$ & $0.60 \pm 0.13$ & $0.63 \pm 0.06$ & $0.61 \pm 0.05$ \\
\hline
\end{tabular}

Table 3: Bacterial percentages ( $>0.48 \%$ ) from incubation water at McNenny State Fish Hatchery incubation water the phylum (class for Proteobacteria) of each genus is listed

\begin{tabular}{|c|c|c|}
\hline Genus & Phylum/Class & Percent \\
\hline Pseudomonas & g-Proteobacteria & 17.23 \\
\hline Massilia & a-Proteobacteria & 9.57 \\
\hline Zoogloea & a-Proteobacteria & 8.08 \\
\hline Leptospirillum & Nitrospirae & 5.64 \\
\hline Rhodococcus & Actinobacteria & 4.61 \\
\hline Enterobacter & g-Proteobacteria & 3.75 \\
\hline Albiferrax & a-Proteobacteria & 3.74 \\
\hline Variovorax & a-Proteobacteria & 2.56 \\
\hline Pleurocapsa & Cyanobacteria & 2.03 \\
\hline Hydrogenophaga & a-Proteobacteria & 1.77 \\
\hline Ferribacterium & a-Proteobacteria & 1.5 \\
\hline Cymbella & Chloroplast & 1.36 \\
\hline Salana & Actinobacteria & 1.35 \\
\hline Stenotrophomonas & g-Proteobacteria & 1.33 \\
\hline Hafnia & g-Proteobacteria & 0.95 \\
\hline Pseudoclavibacter & Actinobacteria & 0.93 \\
\hline Achromobacter & a-Proteobacteria & 0.92 \\
\hline Burkholderia & a-Proteobacteria & 0.92 \\
\hline Rhodococcus & Actinobacteria & 0.79 \\
\hline Leptolyngbya & Cyanobacteria & 0.58 \\
\hline Acinetobacter & g-Proteobacteria & 0.49 \\
\hline
\end{tabular}




\section{Discussion}

It is not surprising that a one-time disinfection prior to disinfection using any of the iodophor solutions did not influence the egg external membrane bacterial communities 28 days later at the eyed stage of development. During incubation in verticalflow tray incubators, salmonid eggs are continuously exposed to bacteria $[5,28]$. In addition, just as in this study, bacterial numbers have been shown to be relatively low prior to and at the start of incubation, with up to 400 fold increases in CFUs by the eyed stage $[5,6]$. The lack of differences among the iodine treatment in bacteria genera present on eyed salmon eggs also indicates that the one-time treatments had little impact on long-term bacterial colonization.

The results of this study indicate that the bacterial species present in hatchery water are not indicative of the bacteria attached to the external membrane of incubating eggs. However, state the bacteria present on fish are similar to those in the surrounding water [2]. While the bacterial profiles of the incubation water and external egg membrane were generally not comparable in this study, it is possible that at least some of the Flavobacterium species abundant on the external egg membrane were derived from the incubation water surrounding the eggs. Incubation water has previously been implicated as an inoculation source for Flavobacterium on Chinook salmon eggs [18]. Although uncommon in McNenny hatchery water, Flavobacterium appear to readily colonize eggs and become major components of the bacterial flora. However, other bacteria, such as Vibrio metschnikovii, were present on the eggs at spawning, and persist on the eggs until maturity. It is interesting to note, however, that Vibrio species were not isolated from in a culturebased survey of ovarian fluid of Chinook salmon [9].

The bacterial genera isolated at the eyed-egg stage during this study show some similarities to those reported by [10 ,18], such as the presence of large numbers of Flavobacterium. However, this study did not observe the relatively high prevalence of Pseudomonas observed by [10]. In addition, the very large contributions of Vibrio and Variovorax, along with Pedobactor and Acidovorax, are unique to this study. Some of these differences could be due to the different incubation loadings used in each study, with higher densities in another study [10], likely producing considerably more available nutrients for bacterial growth $[3,25]$, as well as creating potentially different incubation water quality conditions [27].

The bacterial communities on the external membranes of Chinook salmon eggs after four weeks of incubation are obviously different that of recently-spawned eggs or ovarian fluid $[9,10]$. Of the six bacteria genera isolated from spawning landlocked fall Chinook salmon ovarian fluid by [9], only two were isolated from the eyed eggs in this study. Both of them, Pseudomonas and Acinetobacter, are extremely common in aquatic environments $[13,21,22,24]$. Both have been previously recovered from salmonid gametes $[14,24,26]$, with some species in each genera pathogenic to fish $[4,34]$.

In conclusion, although iodine disinfection treatments on recently fertilized eggs reduced egg bacterial numbers, such treatments had no effect on the abundance or genera of bacteria on eyed eggs after 28 days of incubation. Eyed egg bacterial populations also appeared to be dissimilar to the incubation water. Subsequent research should examine the effects of additional iodine treatments throughout incubation on egg bacterial populations, as well as other novel practices to decrease bacterial loads on incubating eggs.

\section{Acknowledgements}

Thanks for Patrick Nero, Eric Krebs, and Jeremy Keintz for their assistance with this study. This research was supported in part by an Institutional Development Award (IDeA) from the National Institute of General Medical Sciences of the National Institutes of Health under grant number P20GM103443. Its contents are solely the responsibility of the authors and do not necessarily represent official views of NIGMS or NIH.

\section{References}

1. Amend DF, Pietsch JP. Virucidal activity of two iodophors to salmonid viruses. Journal of the Fisheries Research Board of Canada. 1972;29(1):61-65.

2. Austin B, Austin DA. Bacterial fish pathogens: disease in farmed and wild fish. Wiley, New York. 1987.

3. Barker GA, Smith SN, Bromage NR. The bacterial flora of rainbow trout, Salmo gairdneri Richardson, and brown trout, Salmo trutta L., eggs and its relationship to developmental success. Journal of Fish Diseases. 1989;12(4):281-293.

4. Barker GA, Smith SN, Bromage NR. Commensal bacteria and their possible relationship to mortality of incubating salmonid eggs. Journal of Fish Diseases. 1991;14(2):199-201.

5. Barnes ME, Gabel AC, Cordes RJ. Bacterial populations during inland fall Chinook salmon egg culture in vertical-flow incubators. North American Journal of Aquaculture. 1999;61(3):252-257.

6. Barnes ME, Gabel AC, Cordes RJ. Bacterial populations during rainbow trout egg culture in vertical-flow incubators. North American Journal of Aquaculture. 2000;62(1):48-53.

7. Barnes ME, Bergmann D, Stephenson H, Gabel M, Cordes RJ. Bacterial numbers from landlocked fall Chinook salmon eyed eggs subjected to various formalin treatments as determined by scanning electron microscopy and bacteriological culture methods. North American Journal of Aquaculture. 2005;67(1):23-33.

8. Barnes ME, Bergmann D, Jacobs J, Gabel M. Effect of Flavobacterium columnare inoculation, antibiotic treatments and resident bacteria on rainbow trout Orncorhynchus mykiss eyed egg survival and external membrane structure. Journal of Fish Biology. 2009;74(3):576-590.

9. Barnes ME, Bergmann D, Kelley RL, Cordes RJ, Nero PA, Durben DJ. A survey of bacteria in the ovarian fluid of landlocked fall Chinook salmon and their relationship with egg survival. North American Journal of Aquaculture. 2010;72(4):314-320. 
10. Bergmann DJ, Brakke A, Barnes ME. Characterization of bacteria isolated from landlocked fall Chinook salmon eggs from Lake Oahe, South Dakota. North American Journal of Aquaculture. 2013;75(2):159-163.

11. Chalupnicki MA, Ketola HG, Starliper CE, Gallagher D. Efficacy and toxicity of iodine disinfection of Atlantic Salmon eggs. North American Journal of Aquaculture. 2011;73(2):124-128.

12. Collins CH, Lyne PM, Grange JM. Collins and Lyne's Microbiological Methods, 7th ed. Butterworth-Heinemann, Oxford, United Kingdom. 1995.

13.De Sousa JA, Silva-Sousa ÂT. Bacterial community associated with fish and water from Congonhas River, Sertaneja, Parana', and Brazil. Brazilian Archives of Biology and Technology. 2001;44(4):373-381.

14. Kubilay A, Altun S, Savasx S. A study on aerobic bacterial flora during incubation of rainbow trout (Oncorhynchus mykiss, Walbaum 1792) eggs in hatchery. Journal of FisheriesSciences.com. 2009;3(1):5-9.

15. Kuehl R. Design of Experiments: Statistical Principles of Research Design and Analysis, 2nd Ed. Brookes/Cole, Pacific Grove, California, USA. 2000.

16. Kumagai A, Takahashi K, Yamaoka S, Wakabayashi H. Ineffectiveness of iodophore treatment in disinfecting salmonid eggs carrying Cytophaga psychrophila. Fish Pathology. 1998;33(3):123-128.

17. Lahnsteiner F. Effect of iodophor disinfection of non-hardened Salmo trutta eggs on their bacterial and fungus load. Aquaculture Research. 2017;48(7):3901-3909.

18. Loch TP, Faisal M. Flavobacteria colonizing the early life stages of hatcheryincubated Chinook salmon Oncorhynchus tshawytscha (Walbaum 1792) are markedly diverse. J Fish Dis. 2018;41(5):829845. doi: $10.1111 /$ jfd. 12795

19. McFadden TW. Effective disinfection of trout eggs to prevent egg transmission of Aeromonas liquefaciens. Journal of the Fisheries Research Board of Canada. 1969;26(9):2311-2318.

20. MacFaddin JF. Biochemical Tests for Identification of Medical Bacteria, 3rd ed. Williams and Wilkins, Baltimore, Maryland. 2000.

21.Petersen A, Andersen JS, Kaewmak T, Somsiri T, Dalsgaard A. Impact of integrated fish farming on antimicrobial resistance in a pond environment. Appl Environ Microbiol. 2002;68(12):6036-6042.

22.Piper RG, McElwain IB, Orme LE, McCraren JP, Fowler LG, Leonard JR. Fish hatchery management. U.S. Fish and Wildlife Service, Washington, D.C.Post, G. 1987. Textbook of fish health. T.F.H. Publications, Neptune City, New Jersey. 1982.

23. Reasoner DJ, Geldreich EE. A new medium for the enumeration and subculture of bacteria from potable water. Appl Environ. Microbiol. 1985;49(1):1-7.
24.Sauter RW, Williams C, Meyer EA, Celnik B, Banks JL, Leith DA. A study of bacteria present within unfertilized salmon eggs at the time of spawning and their possible relation to early life stage disease. Journal of Fish Diseases. 1987;10(3):193-203.

25.Smith SN, Armstrong RA, Springate J, Barker G. Infection and colonization of trout eggs by Saprolegniaceae. Transactions of the British Mycological Society. 1985;85(4):719-723.

26.Toranzo AE, Combarro P, Lemos ML, Barja JL. Plasmid coding for transferable drug resistance in bacteria isolated from cultured rainbow trout. Applied and Environmental Microbiology. 1984;48(4):872-877.

27. Tortora GJ, Funke BR, Case CL. Microbiology an introduction, 3rd edition. Benjamin/Cummings Publishing, Redwood City, California. 1989.

28.Trust TJ. The bacterial population in vertical flow tray hatcheries during incubation of salmonid eggs. Journal of the Fisheries Research Board of Canada. 1972;29(5):567-571.

29. Wagner EJ, Arndt RE, Billman EJ, Forest A, Cavender W. Comparison of the efficacy of iodine, formalin, salt, and hydrogen peroxide for control of external bacteria on rainbow trout eggs. North American Journal of Aquaculture. 2008;70(2):118-127.

30.Wagner EJ, Oplinger RW, Arndt RE, Forest AM, Bartley M. The safety and effectiveness of various hydrogen peroxide and iodine treatment regimens for rainbow trout egg disinfection. North American Journal of Aquaculture. 2010;72(1):34-42.

31. Wagner EJ, Oplinger RW, Bartkey M. Effect of single or double exposures to hydrogen peroxide or iodine on salmonid egg survival and bacterial growth. North American Journal of Aquaculture. 2012;74(1):84-91.

32.Weisburg WG, Barns SM, Pelletier DA, Lane DJ. 16S ribosomal DNA amplification for phylogenetic study. J Bacteriol. 1991;173(2):697703.

33.Wang Q, Garrity GM, Tiedje JM, Cole JR. Naïve Bayesian Classifier for Rapid Assignment of rRNA Sequences into the New Bacterial Taxonomy. Appl Environ Microbiol. 2007;73(16):5261-5267. doi: 10.1128/AEM.00062-07

34.Xia L, Xiong D, Gu Z, Xu Z, Chen C, Xu P, et al. Recovery of Acinetobacter Baumannii from diseased channel catfish (Ictalurus punctatus) in China. Aquaculture. 2008;284(1-4):285-288.

35.Zawada A, Polechoński R, Bronowska A. Iodine disinfection of sea trout, Salmo trutta (L.), eggs and the affect on egg surfaces. Archive of Polish Fisheries. 2014;22:121-126.

36.Zimbro MJ, Power DA. Difco and BBL Manual- Manual of Microbiological Culture Media. 1981. Becton Dickson and Co., Sparks, Maryland. 1980. 